\title{
Spatial Distribution and Diversity of Bird Community in an Urban Area of Southeast Brazil
}

\author{
Marco Antônio Manhães ${ }^{1 *}$ and Alan Loures-Ribeiro ${ }^{2}$ \\ ${ }^{1}$ Universidade Federal de São Carlos; Instituto de Ciências Biológicas e da Saúde; Pós-graduação em Ecologia e \\ Recursos Naturais; C. P. 676; marcomanhaes@bol.com.br; 13565-905; São Carlos - SP - Brazil; ${ }^{2}$ Universidade \\ Estadual de Maringá; Pós-graduação em Ecologia de Ambientes Aquáticos Continentais; Bloco G-90; \\ brazilraptors@yahoo.com.br; 87020-900; Maringá - PR - Brazil
}

\begin{abstract}
Since the campus of the Federal University of Juiz de Fora, Minas Gerais State, Brazil, has different landscapes, it turns up to be a useful ecological model to evaluate the influence of habitat heterogeneity on bird communities. Our research goals were to know the local avifauna and compare its composition and bird diversity within the different landscapes. Species were identified in point counts without distance estimation, in four habitats: secondary woodlot, lake and surroundings, scrub/abandoned grazing areas and urban areas. One hundred and twenty-one species were identified, but no difference in diversity among the habitats was found. However, analyses indicated the existence of greater similarities among the sampling points belonging to the same kind of habitat. Results suggests that small and isolated forest fragments in urban areas fail to sustain a greater diversity than the adjacent areas, even though the environment's heterogeneous aspect favours local bird richness.
\end{abstract}

Key words: Bird diversity, Southeast Brazil, habitat heterogeneity, urban landscapes

\section{INTRODUCTION}

The heterogeneity of natural environments is one of the most important factors that contribute to an increase in biodiversity (Karr, 1976). In neotropical regions biodiversity comprises a great variety of biomes, high endemism (Gentry, 1986) and heterogeneity of microhabitats (Ricklefs, 1993; Argel-de-Oliveira, 1996). South American fauna, with over 3,000 species, is particularly renowned for its high bird diversity (Bierregaard, 1998).

Although great efforts have been undertaken to restrain the destruction of natural habitats, their transformation into pastures, agricultural and urbanized areas has reduced the spaces for bird survival and has resulted in decline of animal populations (Foster, 1996; Kahn and McDonald, 1997; Hostetler and Knowles-Yanez, 2003). Forest fragmentation or local extinction of certain landscapes, such as mangroves and savannas practically always follows human demographic expansion, since they are usually adjacent to human communities. In spite of the above characteristics, the limits between small forest fragments in urbanized areas with pastures, parks, plantations, and the introduction of native or exotic plant species contribute towards the formation of diversified common landscapes (Argel-de-Oliveira, 1996) in southeastern Brazil, the most urbanized region of the country. This situation has enhanced studies on the dynamics of

\footnotetext{
*Author for correspondence
} 
avifauna in urban areas (Argel-de-Oliveira, 1995; Gimenes and Anjos 2000; Krügel and Anjos, 2000) and provided subsidies for conservation and management strategies.

If urbanization eventually is unavoidable at a given moment and place, city planners may administer landscapes, albeit artificial, so that they can attract and sustain the highest range of birds species. In this context and because of its heterogeneous landscape, the campus of the Federal University of Juiz de Fora represents a useful model. The goals of this work were: (1) to know the local avifauna, (2) to compare bird diversity in the distinct existing landscapes and (3) to establish their similarities while focusing on the causes of the ecological processes.

\section{MATERIALS AND METHODS}

The study was carried out at the campus of the Federal University of Juiz de Fora (UFJF, $21^{\circ} 46^{\prime}$ $\left.\mathrm{S}, 43^{\circ} 21^{\prime} \mathrm{W}\right)$, Minas Gerais State, southeastern Brazil. The campus, at $720-931 \mathrm{~m}$ a. s. 1., has a total area of 83.16 ha, typical humid subtropical climate or Cwa by Köppen's classification, and an annual average temperature of $18.7^{\circ} \mathrm{C}$ (Almeida, 1996).

The area predominantly comprises four types of well-defined environments (habitats): lake with dense surrounding vegetation (L), scrubs and abandoned grazing areas (S), urbanized areas (U), secondary forest (woodlot, W). There are two small secondary Atlantic rainforest fragments (4.5 and 1.5 ha) and Euphorbiaceae, Myrtaceae, Lauraceae and Mimosaceae predominate in the larger woodlot (Almeida, 1996). The lake surroundings form a predominantly bamboo (Phyllostachys aurea, Poaceae) belt. Species of Myrtaceae, Melastomataceae and other less representative families, occur on another belt around the lake, adjacent to the above-mentioned woodlot. Melinis minutiflora (Poaceae) and some Caesalpinaceae species predominate in the scrub areas, while within the more urbanized areas predominate exotic species such as Pinnus elliottii (Pinnaceae), Spatodea campanulata (Bignoniaceae), Eritrina speciosa (Faboideae), Casuarina sp (Casuarinaceae) and other plants belonging to the Bignoniaceae, Caesalpiniaceae, Palmae and Melastomataceae families.

Bird survey was carried out between May and July 2002, using point counts without distance estimation method (Wunderle, 1994). Four fixed sampling points were plotted in each one of the four habitats. Samplings were carried out in the first morning hours, soon after sunrise, at two or four points/day, chosen randomly. A minimum distance of 100 meters between the 16 points was generally maintained. Samplings of forest environments were actually concentrated in the 4.5 ha woodlot. Owing to size, proximity and distribution of the sampled areas, some intervals were smaller. The sampling of below $100 \mathrm{~m}$ distance points on the same day was avoided so that data-dependent problems could be minimized. Sampling time for any point was $20 \mathrm{~min}$, whereas sampled points were off-scored from the next draw till the 16 points had been sampled. During this period all bird species, identified by their vocalizations or by direct observation with binoculars within the sample habitat, were recorded. Each record merely accounted for the presence or absence of the species in the point. In spite of possible bias in counting birds by presence/absence data, this procedure was adopted to minimize problems in counting individuals belonging to species with different degrees of conspicuity in heterogeneous landscapes.

One hundred and twelve samplings were undertaken (seven for each point, 28 for each habitat), totaling 37.3 sampling hours. Field activities occurred during the non-breeding period of most of the species and prior to the arrival of spring/summer migrants.

The birds were grouped into trophic guilds, based on Willis (1979), Karr et al. (1990), Anjos (2001), Santos (2001), and field observations. The degree of forest dependence $(\mathrm{Fd})$ of species with 20 or more records was established according to Silva (1995) and Andrade and Marini (2002). The patterns of habitat distribution of these species were tested using Chi-square for homogeneous frequencies, according to Fowler et al. (1998).

Diversity was calculated by jack-knife estimator (VPi) (Magurran, 1988), using the ShannonWiener diversity index. Kruskal-Wallis nonparametric test was used to test the differences between habitat diversity estimates. Sampling points were grouped according to presence/absence data of the species by Cluster Analysis, using Euclidean distance and UPGMA. The cophenetic coefficient for the similarity matrix was calculated by NTSYS-PC 1.8 to verify possible cluster distortions (Rohlf, 1996, DinizFilho and Bini, 1996). With regard to the 
cophenetic value test, 9,999 permutations were generated in order to obtain the stabilization of the data matrix. Hummingbirds identified just below family level and species observed exclusively outside the points were excluded from analyses.

Bird taxonomy and nomenclature followed Sick (1997).

\section{RESULTS}

One hundred and twenty-one species belonging to 14 orders and 30 families were identified, including those recorded exclusively outside the points. Passeriformes constituted the predominant group, representing $46.7 \%$ of families $(n=14)$ and $65.3 \%$ of species $(n=79)$. The families with the largest number of species were Emberizidae $(\mathrm{n}=29)$ and Tyrannidae $(\mathrm{n}=26)$ (Table 1$)$.

Table 1 - Avifauna of UFJF. Species $(\mathbf{0})$ : species recorded out of the sampling points. $\chi^{2}$ results: $\mathbf{N S}=$ nonsignificant $(\mathrm{p}>0,05)$; Significant, $(*)=\mathrm{p}<0,05,(* *)=\mathrm{p}<0,01,(* * *)=\mathrm{p}<0,001$. L/W/S/U: Number of observations in the Lake/Woodlot/Scrub/Urban habitats. Fd: degree of forest dependence, $\mathbf{i}=$ independent, $\mathbf{s d}=$ semi-dependent, $\mathbf{d}=$ dependent. TG: Trophic guild, C: carnivore; Cr: Carrion-eating; F: frugivores; G: granivore; GF: granivore/Frugivore; I: insectivore; N: nectarivore; O: omnivore; P: piscivore.

\begin{tabular}{|c|c|c|c|c|}
\hline $\begin{array}{r}\text { species } \\
\end{array}$ & $\mathbf{L} / \mathbf{W} / \mathbf{S} / \mathbf{U}$ & $x^{2}$ & Fd & TG \\
\hline $\begin{array}{l}\text { Phalacrocoracidae } \\
\text { Phalacrocorax brasilianus } \\
\text { Ardeidae }\end{array}$ & $1 / 0 / 0 / 0$ & & $\mathrm{i}$ & $\mathrm{P}$ \\
\hline Ardeidae & & & & \\
\hline Casmerodius albus & $1 / 0 / 0 / 0$ & & $\mathrm{i}$ & $\mathrm{C}$ \\
\hline $\begin{array}{l}\text { Butorides striatus } \\
\text { Cathartidae }\end{array}$ & $7 / 0 / 0 / 0$ & & $\mathrm{i}$ & $\mathrm{C}$ \\
\hline $\begin{array}{l}\text { Amazonetta brasiliensis } \\
\text { Accipitridae }\end{array}$ & $2 / 0 / 0 / 0$ & & $\mathrm{i}$ & $\mathrm{O}$ \\
\hline Buteo albicaudatus & $0 / 0 / 1 / 0$ & & $\mathrm{i}$ & $\mathrm{C}$ \\
\hline Rupornis magnirostris & $0 / 2 / 3 / 2$ & & $\mathrm{i}$ & $\mathrm{C}$ \\
\hline $\begin{array}{l}\text { Buteogallus meridionalis } \\
\text { Falconidae }\end{array}$ & $0 / 1 / 0 / 0$ & & $\mathrm{i}$ & $\mathrm{C}$ \\
\hline Milvago chimachima & $0 / 2 / 2 / 1$ & & $\mathrm{i}$ & $\mathrm{C}$ \\
\hline Caracara plancus & $0 / 0 / 5 / 0$ & & $\mathrm{i}$ & $\mathrm{C}$ \\
\hline Falco femoralis & $0 / 1 / 0 / 0$ & & $\mathrm{i}$ & $\mathrm{C}$ \\
\hline $\begin{array}{l}\text { Penelope superciliaris } \\
\text { Rallidae }\end{array}$ & $1 / 0 / 0 / 0$ & & $\mathrm{~d}$ & $\mathrm{~F}$ \\
\hline 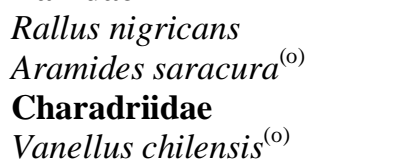 & $1 / 0 / 0 / 0$ & & $\begin{array}{l}\text { sd } \\
\text { sd }\end{array}$ & $\begin{array}{l}\mathrm{O} \\
\mathrm{O}\end{array}$ \\
\hline Columbidae & & & & \\
\hline Columba picazuro & $13 / 2 / 0 / 11$ & $\begin{array}{c}* * \\
*\end{array}$ & sd & GF \\
\hline Columba cayennensis & $10 / 1 / 0 / 0$ & & $\mathrm{~d}$ & GF \\
\hline Columba livia $^{(\mathrm{o})}$ & & & $\mathrm{i}$ & $\mathrm{G}$ \\
\hline Zenaida auriculata & $0 / 0 / 0 / 2$ & & $\mathrm{i}$ & GF \\
\hline Columbina talpacoti & $1 / 0 / 4 / 6$ & & $\mathrm{i}$ & G \\
\hline Leptotila verreauxi & 2/11/0/0 & & sd & GF \\
\hline Leptotila rufaxilla & $1 / 11 / 4 / 1$ & & $\mathrm{~d}$ & GF \\
\hline Psittacidae & & & & \\
\hline Propyrrhura maracana & $1 / 2 / 0 / 0$ & & sd & $\mathrm{F}$ \\
\hline Aratinga leucophthalmus & $1 / 5 / 1 / 3$ & & sd & $\mathrm{F}$ \\
\hline Aratinga aurea & $0 / 0 / 6 / 2$ & & $\mathrm{i}$ & $\mathrm{F}$ \\
\hline Forpus xanthopterygius & $1 / 6 / 0 / 2$ & & $\mathrm{i}$ & $\mathrm{F}$ \\
\hline
\end{tabular}




\begin{tabular}{|c|c|c|c|c|}
\hline Pionus maximiliani & $0 / 5 / 0 / 2$ & & sd & $\mathrm{F}$ \\
\hline \multicolumn{5}{|l|}{ Cuculidae } \\
\hline species & $\mathbf{L} / \mathbf{W} / \mathbf{S} / \mathbf{U}$ & $\chi^{2}$ & Fd & TG \\
\hline Piaya cayana & $5 / 3 / 0 / 4$ & & sd & I \\
\hline Crotophaga ani & $2 / 0 / 7 / 0$ & & $\mathrm{i}$ & I \\
\hline Guira guira & $0 / 0 / 1 / 0$ & & $\mathrm{i}$ & I \\
\hline \multicolumn{5}{|l|}{ Trochilidae } \\
\hline Phaetornis pretrei & $3 / 3 / 0 / 3$ & & sd & $\mathrm{N}$ \\
\hline Eupetomena macroura & $2 / 3 / 9 / 8$ & NS & $\mathrm{i}$ & $\mathrm{N}$ \\
\hline Chlorostilbon aureoventris & $1 / 6 / 3 / 0$ & & sd & $\mathrm{N}$ \\
\hline Amazilia fimbriata & $1 / 4 / 0 / 0$ & & sd & $\mathrm{N}$ \\
\hline Amazilia lactea $^{(\mathrm{o})}$ & & & $\mathrm{d}$ & $\mathrm{N}$ \\
\hline Trochilidae unidentified & $11 / 9 / 10 / 5$ & & & \\
\hline \multicolumn{5}{|l|}{ Alcedinidae } \\
\hline Ceryle torquata & $2 / 0 / 0 / 0$ & & $\mathrm{i}$ & $\mathrm{P}$ \\
\hline \multicolumn{5}{|l|}{ Bucconidae } \\
\hline Nystalus chacuru & $0 / 0 / 1 / 0$ & & $\mathrm{i}$ & I \\
\hline \multicolumn{5}{|l|}{ Picidae } \\
\hline Picumnus cirratus & $7 / 16 / 2 / 10$ & $* *$ & sd & I \\
\hline Colaptes campestris & $0 / 0 / 11 / 1$ & & $\mathrm{i}$ & I \\
\hline Colaptes melanochloros & $1 / 1 / 0 / 1$ & & sd & I \\
\hline Melanerpes candidus & $0 / 0 / 0 / 1$ & & sd & I \\
\hline Veniliornis spilogaster & $1 / 4 / 0 / 1$ & & sd & I \\
\hline \multicolumn{5}{|l|}{ Formicariidae } \\
\hline Thamnophilus caerulescens & $6 / 15 / 0 / 4$ & $* * *$ & $\mathrm{~d}$ & I \\
\hline Thamnophilus ruficapillus & $0 / 1 / 6 / 0$ & & sd & I \\
\hline \multicolumn{5}{|l|}{ Conopophagidae } \\
\hline Conopophaga lineata & $9 / 5 / 0 / 0$ & & $\mathrm{~d}$ & I \\
\hline \multicolumn{5}{|l|}{ Furnariidae } \\
\hline Furnarius rufus & $0 / 0 / 15 / 3$ & & $\mathrm{i}$ & I \\
\hline Furnarius leucopus & $1 / 0 / 0 / 0$ & & sd & I \\
\hline Synallaxis spixi & $0 / 4 / 19 / 7$ & $* * *$ & sd & I \\
\hline Synallaxis ruficapilla & $4 / 9 / 0 / 0$ & & $\mathrm{~d}$ & I \\
\hline Certhiaxis cinnamomea & $1 / 0 / 0 / 0$ & & $\mathrm{i}$ & I \\
\hline $\begin{array}{l}\text { Phacellodomus } \\
\text { erythrophthalmus }\end{array}$ & $10 / 19 / 0 / 0$ & $* * *$ & $\mathrm{~d}$ & I \\
\hline Phacellodomus rufifrons & $0 / 1 / 13 / 5$ & & sd & I \\
\hline \multicolumn{5}{|l|}{ Tyrannidae } \\
\hline Phyllomyias fasciatus & $0 / 2 / 0 / 2$ & & sd & I \\
\hline Camptostoma obsoletum & $5 / 5 / 6 / 13$ & NS & $\mathrm{i}$ & $\mathrm{O}$ \\
\hline Elaenia flavogaster & $1 / 1 / 4 / 9$ & & sd & $\mathrm{O}$ \\
\hline Elaenia obscura & $0 / 2 / 0 / 0$ & & $\mathrm{~d}$ & $\mathrm{O}$ \\
\hline Serpophaga subcristata & $6 / 2 / 8 / 14$ & $*$ & sd & I \\
\hline Mionectes rufiventris & $2 / 1 / 0 / 0$ & & $\mathrm{~d}$ & $\mathrm{O}$ \\
\hline Phylloscartes ventrallis & $0 / 0 / 0 / 1$ & & $\mathrm{~d}$ & $\mathrm{I}$ \\
\hline Todirostrum poliocephalum & $0 / 5 / 0 / 0$ & & $\mathrm{~d}$ & I \\
\hline Todirostrum plumbeiceps & $9 / 15 / 6 / 0$ & $* *$ & $\mathrm{~d}$ & I \\
\hline Tolmomyias sulphurescens & $11 / 14 / 1 / 0$ & $* * *$ & $\mathrm{~d}$ & I \\
\hline Platyrhinchus mystaceus & $6 / 0 / 0 / 0$ & & $\mathrm{~d}$ & I \\
\hline Myiophobus fasciatus & $0 / 0 / 4 / 0$ & & $\mathrm{i}$ & I \\
\hline Lathrotriccus euleri & $1 / 1 / 0 / 0$ & & $\mathrm{~d}$ & I \\
\hline Xolmis cinerea $^{(\mathrm{o})}$ & & & $\mathrm{i}$ & I \\
\hline Knipolegus lophotes & $0 / 1 / 2 / 0$ & & $\mathrm{i}$ & I \\
\hline Colonia colonus & $0 / 4 / 0 / 0$ & & $\mathrm{~d}$ & I \\
\hline Satrapa icterophrys & $0 / 0 / 0 / 1$ & & $\mathrm{i}$ & I \\
\hline Hirundinea ferruginea ${ }^{(0)}$ & & & sd & I \\
\hline
\end{tabular}


Cont. Table 1

\begin{tabular}{|c|c|c|c|c|}
\hline Machetornis rixosus & 0/0/0/1 & & $\mathrm{i}$ & I \\
\hline Fluvicola nengeta & $11 / 0 / 0 / 0$ & & $\mathrm{i}$ & I \\
\hline species & $\mathbf{L} / \mathbf{W} / \mathrm{S} / \mathbf{U}$ & $x^{2}$ & Fd & TG \\
\hline Myiarchus ferox & $12 / 3 / 2 / 4$ & $* *$ & $\mathrm{sd}$ & I \\
\hline Pitangus sulphuratus & $22 / 17 / 16 / 21$ & NS & $\mathrm{i}$ & $\mathrm{O}$ \\
\hline Megarhynchus pitangua & $2 / 6 / 0 / 7$ & & $\mathrm{sd}$ & $\mathrm{O}$ \\
\hline Tyrannus melancholicus & $1 / 0 / 0 / 0$ & & $\mathrm{i}$ & I \\
\hline Myiozetetes similis & $10 / 5 / 2 / 7$ & $*$ & $\mathrm{sd}$ & $\mathrm{O}$ \\
\hline Pachyramphus polychopterus & $0 / 1 / 0 / 0$ & & $\mathrm{sd}$ & I \\
\hline \multicolumn{5}{|l|}{ Hirundinidae } \\
\hline Progne chalybea ${ }^{(\mathrm{o})}$ & & & $\mathrm{i}$ & I \\
\hline Notiochelidon cyanoleuca & $2 / 0 / 1 / 2$ & & $\mathrm{i}$ & I \\
\hline Stelgydopteryx ruficollis & $1 / 0 / 4 / 0$ & & $\mathrm{i}$ & I \\
\hline \multicolumn{5}{|l|}{ Corvidae } \\
\hline Cyanocorax cristatellus & $0 / 1 / 0 / 0$ & & $\mathrm{i}$ & $\mathrm{O}$ \\
\hline \multicolumn{5}{|l|}{ Troglodytidae } \\
\hline Troglodytes aedon & $13 / 5 / 25 / 18$ & ** & $\mathrm{i}$ & I \\
\hline \multicolumn{5}{|l|}{ Muscicapidae } \\
\hline Turdus rufiventris & 19/13/4/13 & $*$ & $\mathrm{i}$ & $\mathrm{O}$ \\
\hline Turdus leucomelas & $18 / 11 / 5 / 15$ & NS & $\mathrm{sd}$ & $\mathrm{O}$ \\
\hline \multirow{2}{*}{\multicolumn{5}{|c|}{ Mimidae }} \\
\hline & & & & \\
\hline Mimus saturninus & $0 / 0 / 8 / 0$ & & $\mathrm{i}$ & $\mathrm{O}$ \\
\hline \multicolumn{5}{|l|}{ Vireonidae } \\
\hline Cyclarhis gujanensis & $4 / 11 / 0 / 8$ & ** & $\mathrm{sd}$ & I \\
\hline Hylophilus poecilotis & $0 / 6 / 0 / 0$ & & $\mathrm{~d}$ & I \\
\hline \multicolumn{5}{|l|}{ Emberizidae } \\
\hline Basileuterus culicivorus & 18/17/0/6 & $* * *$ & $\mathrm{~d}$ & I \\
\hline Coereba flaveola & $19 / 16 / 9 / 24$ & NS & $\mathrm{sd}$ & $\mathrm{O}$ \\
\hline Schistochlamys ruficapillus & $0 / 0 / 3 / 0$ & & $\mathrm{i}$ & $\mathrm{O}$ \\
\hline Thlypopsis sordida & $2 / 3 / 0 / 0$ & & $\mathrm{sd}$ & $\mathrm{O}$ \\
\hline Hemithraupis ruficapilla & $1 / 3 / 1 / 3$ & & $\mathrm{~d}$ & $\mathrm{~F}$ \\
\hline Tachyphonus coronatus & $3 / 13 / 4 / 12$ & $*$ & $\mathrm{~d}$ & $\mathrm{O}$ \\
\hline Trichothraupis melanops & $3 / 14 / 1 / 3$ & $* * *$ & $\mathrm{~d}$ & $\mathrm{O}$ \\
\hline Piranga flava & 0/0/0/1 & & $\mathrm{i}$ & $\mathrm{O}$ \\
\hline Thraupis sayaca & $8 / 12 / 9 / 23$ & $*$ & $\mathrm{sd}$ & $\mathrm{O}$ \\
\hline Thraupis ornata & $0 / 0 / 0 / 1$ & & $\mathrm{sd}$ & $\mathrm{O}$ \\
\hline Thraupis palmarum & $0 / 0 / 0 / 2$ & & $\mathrm{sd}$ & $\mathrm{O}$ \\
\hline Euphonia chlorotica & $1 / 6 / 0 / 1$ & & $\mathrm{sd}$ & $\mathrm{F}$ \\
\hline Tangara cyanoventris & $1 / 7 / 1 / 11$ & $* *$ & $\mathrm{~d}$ & $\mathrm{O}$ \\
\hline Tangara cayana & $6 / 5 / 5 / 12$ & NS & $\mathrm{i}$ & $\mathrm{O}$ \\
\hline Dacnis cayana & $0 / 1 / 3 / 3$ & & $\mathrm{sd}$ & $\mathrm{O}$ \\
\hline Tersina viridis & $0 / 1 / 0 / 0$ & & $\mathrm{~d}$ & $\mathrm{O}$ \\
\hline Conirostrum speciosum & $0 / 1 / 0 / 4$ & & $\mathrm{~d}$ & I \\
\hline Zonotrichia capensis & $2 / 0 / 6 / 17$ & $* * *$ & $\mathrm{i}$ & G \\
\hline Ammodramus humeralis $^{(0)}$ & & & $\mathrm{i}$ & $\mathrm{G}$ \\
\hline Sicalis flaveola & $0 / 0 / 1 / 2$ & & $\mathrm{i}$ & G \\
\hline Volatinia jacarina & $0 / 0 / 20 / 3$ & $* * *$ & $\mathrm{i}$ & $\mathrm{G}$ \\
\hline Sporophila caerulescens & $0 / 1 / 3 / 2$ & & $\mathrm{i}$ & $\mathrm{G}$ \\
\hline Arremon taciturnus & $0 / 3 / 0 / 0$ & & $\mathrm{~d}$ & $\mathrm{O}$ \\
\hline Coryphospingus pileatus & $0 / 0 / 3 / 0$ & & $\mathrm{sd}$ & G \\
\hline Saltator similis & $0 / 5 / 0 / 0$ & & $\mathrm{sd}$ & $\mathrm{O}$ \\
\hline Psarocolius decumanus & $0 / 1 / 0 / 1$ & & $\mathrm{~d}$ & $\mathrm{O}$ \\
\hline Agelaius ruficapillus & $0 / 0 / 1 / 0$ & & $\mathrm{i}$ & $\mathrm{G}$ \\
\hline Gnorimopsar chopi & $0 / 0 / 1 / 0$ & & $\mathrm{i}$ & $\mathrm{F}$ \\
\hline Molothrus bonariensis & $0 / 0 / 0 / 1$ & & $\mathrm{i}$ & $\mathrm{O}$ \\
\hline
\end{tabular}




\begin{tabular}{lcccc} 
Cont. Table 1 & & & \\
\hline Fringillidae & & & $\mathrm{i}$ & $\mathrm{G}$ \\
Carduelis magellanicus & $0 / 1 / 6 / 13$ & $* * *$ & $\mathbf{F d}$ & $\mathbf{T G}$ \\
species & L/W/S/U & $\chi^{2}$ & $\mathrm{i}$ & $\mathrm{O}$ \\
Passeridae & $0 / 1 / 4 / 7$ & & $\mathrm{i}$ & $\mathrm{G}$ \\
$\begin{array}{l}\text { Passer domesticus } \\
\text { Estrildidae }\end{array}$ & & & \\
Estrilda astrild & $0 / 0 / 12 / 1$ & & $\mathrm{i}$ \\
\hline
\end{tabular}

Table 2 - Species richness of each habitat and occurrence of exclusive species.

\begin{tabular}{lcc}
\hline Habitat & $\begin{array}{c}\text { Total of } \\
\text { Species/ }(\%) *\end{array}$ & $\begin{array}{c}\text { Exclusive } \\
\text { species/(\%)** }\end{array}$ \\
\hline Woodlot & $72(60,3)$ & $11(15,3)$ \\
Lake & $63(55,4)$ & $12(19,0)$ \\
Urban & $63(52,1)$ & $9(14,3)$ \\
Scrub & $57(50,4)$ & $10(17,5)$ \\
\hline
\end{tabular}

*percentage in relation to the total number of species;

*** percentage in relation to the total number of species in each habitat.

Species reported regularly in the campus area prior to start of research could be added to the list obtained during the sampling period since they also represented the local avifauna: Athene cunicularia, not sampled during observation period, Hydropsalis brasiliana, a crepuscular/nocturnal species, Myiodinastes maculatus, Tyrannus savanna and Vireo olivaceus, these last three species being spring/summer migrants (Manhães, pers. obs.).

The woodlot was the habitat with the highest species richness. Two migrant species, Satrapa icterophrys and Molothrus bonariensis, recorded in the last samplings, increased the richness and the number of exclusive species of the urban habitat. It was, nevertheless, the environment with the lowest percentage of exclusive species. The slightly higher percentage of species observed exclusively in the lake area may be accounted for by species dependent on flooded environments, especially Ceryle torquata, Casmerodius albus and Butorides striatus (Table 2). Exclusive species corresponded to $33.9 \%(n=41)$ of total avifauna. Insectivorous and omnivorous species constituted the predominant trophic guilds in all habitats. Ratio decrease of these guilds, mainly in urbanized areas and scrubs, was reported, whereas more granivorous species were detected in these habitats than elsewhere (Fig. 1). There was no difference in diversity $(\mathrm{KW}=3.79 ; \mathrm{p}=0.285)$. The woodlot had the highest VPi (4.47), whereas the lowest occurred in the urban area (3.54). The lowest VPi variation was reported in the lake (Fig. 2).

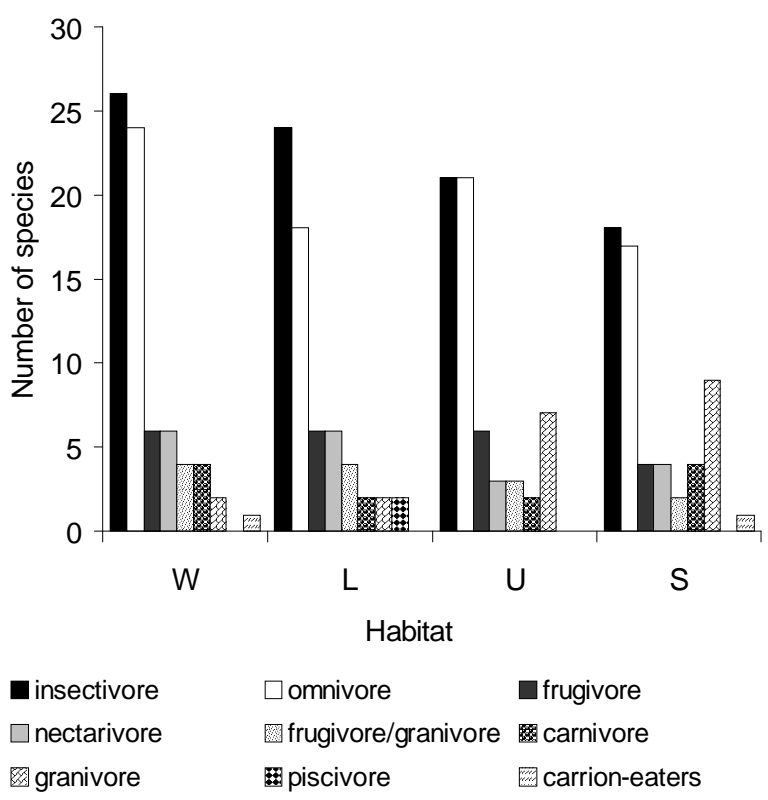

Figure 1 - Distribution of bird trophic guilds at the UFJF habitats. W: Woodlot; L: Lake; U: Urban; S: Scrub.

Nineteen $(70.4 \%)$ of the 27 species, tested for distribution patterns in the habitats, presented significant Fd results (Table 1). Similar to forest 
semi-dependent species, Columba picazuro and Cyclarhys gujanensis, should mainly occur in the woodlot or in the lake (due to the riparian forest belt), but they could visit other habitats regularly. In both cases, the urban habitat had the second highest frequency. Forest-dependent birds should occur with highest frequency in the woodlot or lake, while forest-independent species should occur more frequently either in other habitats or exhibit no preference for any. On the other hand, eight species (29.6\%) (Synallaxis spixi, Serpophaga subcristata, Turdus rufiventris, Turdus leucomelas, Coereba flaveola, Tachyphonus coronatus, Thraupis sayaca, Tangara cyanoventris) did not show significant Fd results.

Lake and woodlot avifauna were the most balanced in Fd. Forest-dependent species in the urbanized areas and scrubs decreased expressively, although semi-dependent species occurred in larger proportions than the independent ones in the latter (Fig. 3).

The cophenetic cluster coefficients indicated a low adjustment to the data matrix (correlation matrix $r=0.412$ ), but Cluster Analysis revealed greater similarities among sampling points belonging to the same kind of habitat. Four distinct groups (C1 - C3; C4 - U4; L1 - L2; M2 - M1) were clearly identified (Fig. 4).

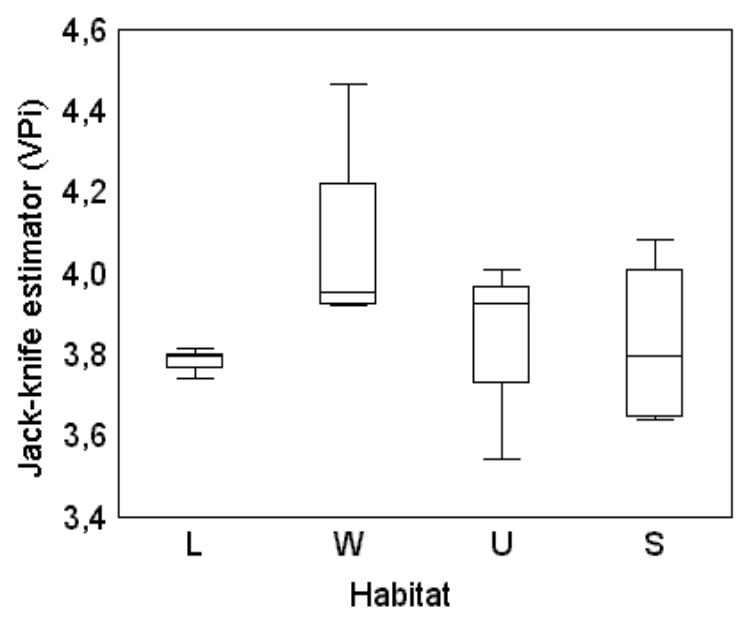

Figure 2 - Bird diversity variation at the UFJF habitats. Horizontal lines into the boxplots represent medians. Habitats as in Fig. 1.

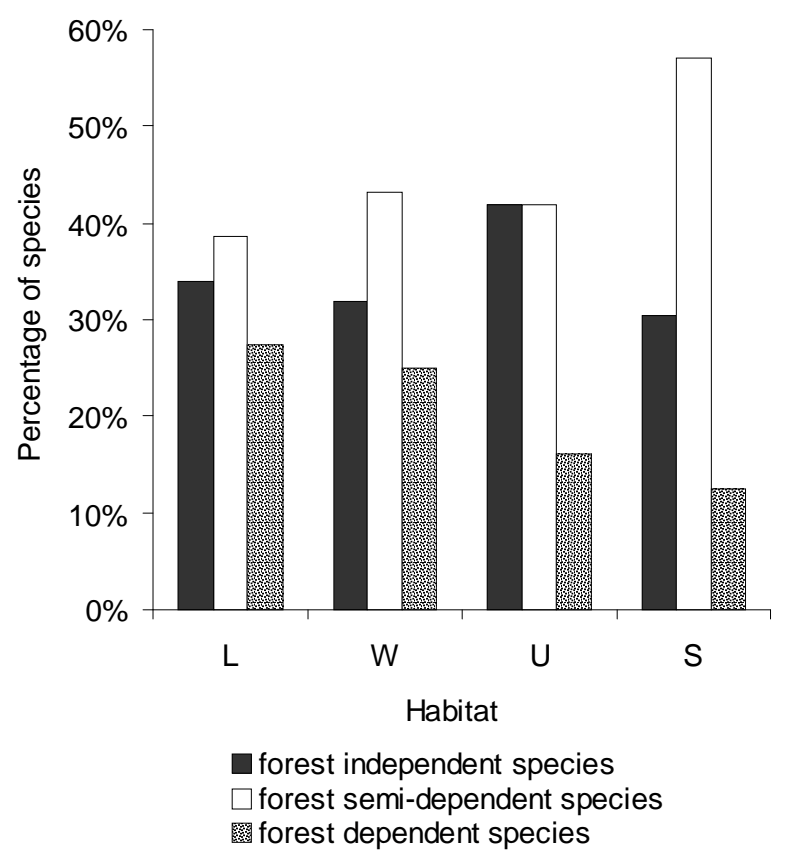

Figure 3 - Proportional composition of bird species at the UFJF habitats, according to the degree of forest dependence $(\mathrm{Fd})$. Habitats as in Fig. 1.

\section{DISCUSSION}

Twenty-seven species (23.9\%), among those listed, had at least 20 contacts. This fact suggested that the bird community was dominated by few species; most had low frequency, probably due to the small populations size. The community also comprised many wide-range and non-native species. Similar results were also found by Almeida et al. (1999) in riparian forests fragments in the São Paulo State, and by Gimenes and Angels (2000) in small forest fragments in the Paraná State, where study areas had been affected by human activity. These patterns could occur because urban expansion led to the loss of wildlife habitats (Hostetler and Knowles-Yanez, 2003) due to a decrease in vegetation and subsequently to a proportional loss of biodiversity (Savard et al., 2000). Melles et al. (2003) reported that forests near urbanized landscapes formed resource areas for resident birds and origin areas for vagrants. In the UFJF neighborhood, forests patches are still existing and they could be an asset for birds that do not reproduce in the campus, especially largesized birds or those with great capacity to move 
among forest fragments, as the case with certain Falconiformes and Psittaciformes. Although the avifauna composed mainly by little habitatdemanding species, even those species that nested in the area must search alternative sources outside the campus during periods of shortage. This fact contributed towards a reduced observation frequency of the birds.

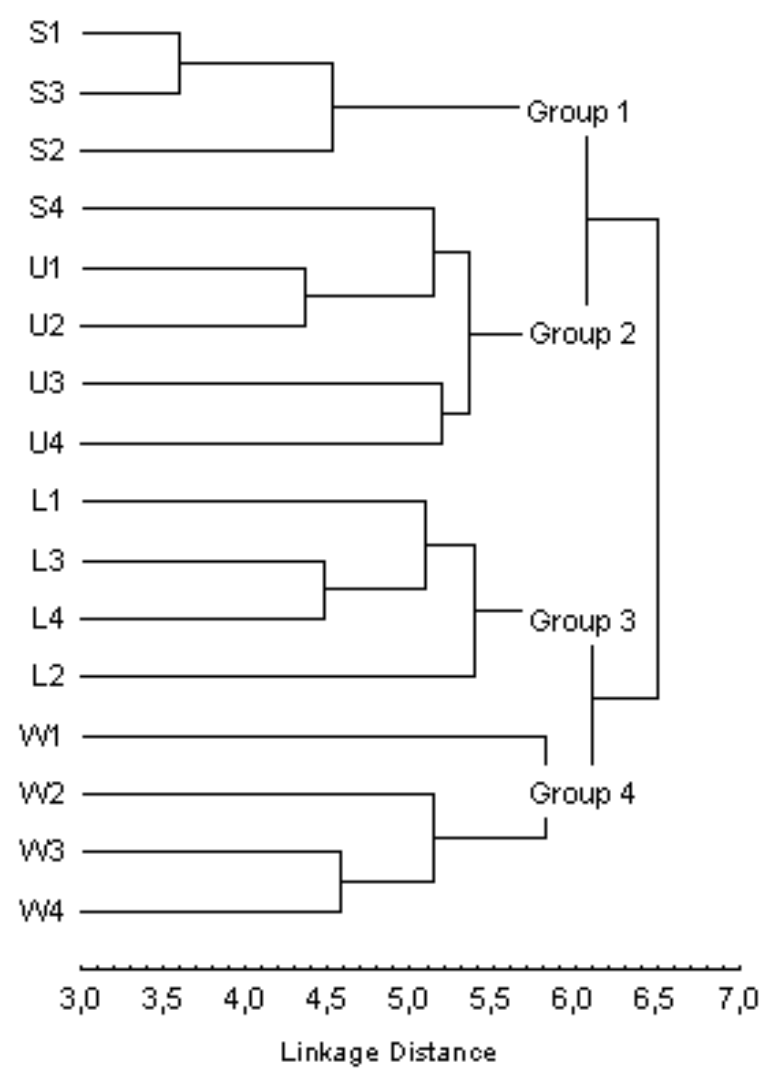

Figure 4 - Cluster analysis of the sampling points obtained by means of UPGMA and Euclidean distance, from presence/absence data of species. Habitats as in Fig. 1.

Birds of generalist feeding habits were predominant in the composition of the local avifauna. Since less specialized omnivorous and insectivorous species were greatly predominant, studies that revealed that these trophic guilds benefited from habitat destruction (Willis, 1979; Motta Jr., 1990) and from an increase in built-up area (Jokkimäki and Suhonen, 1998) were corroborated.
All habitats had certain particularities to attract mainly birds of great ecological amplitude and percentages of exclusive species were very similar. Nevertheless, as a whole, the proportion of these species could be considered high. The importance of habitat heterogeneity in the UFJF campus was sustained by the clustering of sampling points. Groups showed clearly that each habitat had its own characteristics with regard to avifauna composition.

The woodlot maintained the former natural characteristics found in the region. Although at present surrounded by artificially-created landscapes or by widely urbanized areas, this forest fragment benefited the exchange of typical forest-dwelling species, which moved to adjacent areas, mainly to the lake surroundings. A similar process should also occur in the smaller fragment $(1.5 \mathrm{ha})$ close to urbanized areas and scrubs. However, the studied fragment did not sustain a diversity larger than that of the other habitats. According to Beissinger and Osborne (1982), forest patches available for birds in urban areas were smaller than the threshold size required by many species. In this case, the secondary isolated 4.5 ha-forest fragment was insufficient to support bird diversity greater than that of the surrounding areas. However, the forest environment caused an increment in species richness on the campus as a whole. This was due to the typical forest birds. The woodlot was also important for diversity balance and maintenance, mainly due to its regular use by some species, even though they were not exclusive forest ones. Besides the physical proximity, the flow increase of forest-independent and semi-dependent species could be caused by the edge effect (Gimenes and Angels, 2000; Krügel and Anjos, 2000), which, due to its small size and elongated form, should extend to the whole fragment.

Vegetation increase within an urban area should benefit bird abundance and diversity (Savard et al. 2000). However, according to Beissinger and Osborne (1982), the type of vegetation coverage also influenced avian communities. Thus, the maintenance of bamboos in the lake surroundings and scrubs turns up to be important, since the latter becomes havens for bird species with their own ecological requirements. For instance, the forestdependent species Conopophaga lineata and Todirostrum plumbeiceps, were frequently reported in the bamboos on the lake margin. It 
could be concluded that habitat heterogeneity promoted an increase in the range of these species. Scrubs support herbaceous and shrubbery vegetation and may favor an increase of species richness and diversity, due to the presence of species that nest and forage in these locations (Savard et al, 2000). Volatinia jacarina, Sporophila caerulescens, Zonotrichia capensis, Estrilda astrild and Carduelis magellanicus were the campus species most dependent on urban and scrub areas for nesting and eating grass seeds, which increased the percentage of granivorous species. A Psittacidae, Aratinga aurea, was only reported in these habitats.

An increment in forest area is very important for the recovery of bird diversity on the studied site and in other urbanized areas. However, in the wake of space limitations to recover urban forests, it is necessary to plan conservation, albeit artificial, of other kind of habitats. In some cases, these habitats may supply refuges and food resources for birds. Results of our research point towards the maintenance of these habitats for the preservation of avifauna composition.

\section{ACKOWLEDGEMENTS}

We would like to thank Mr. Ricardo Montianele de Castro and Prof. Márcio Caetano Brügger (Botany Department, Institute of Biological Sciences, UFJF) for the identification of plant families and species. Thanks are also due to Prof. Fábio Roland (Biology Department) for his logistic support and Artur Andriolo (Zoology Department) for their valuable contribution to the manuscript.

\section{RESUMO}

O Campus da Universidade Federal de Juiz de Fora possui diferentes paisagens e pode representar um modelo ecológico útil para avaliar a influência da heterogeneidade de hábitats sobre a diversidade de aves. Os objetivos deste trabalho foram conhecer a avifauna local e comparar a composição e diversidade de aves nas distintas paisagens existentes. As espécies foram identificadas em pontos de contagem, em quatro hábitats: mata secundária, lago e arredores, capoeira/pastagem abandonada e urbanizada/jardinada. Foram identificadas 121 espécies, mas não houve diferença de diversidade entre os hábitats. Entretanto, as análises indicaram a existência de maiores similaridades entre os pontos amostrais pertencentes ao mesmo tipo de hábitat. Os resultados sugerem que pequenos fragmentos de mata fortemente isolados em áreas urbanas não sustentam uma diversidade maior do que as áreas adjacentes mas o aspecto heterogêneo do ambiente pode favorecer a riqueza de aves local.

\section{REFERENCES}

Almeida, D. S. (1996), Florística e estrutura de um fragmento de floresta atlântica, no município de Juiz de Fora, Minas Gerais. M.Sc. Thesis - Federal University of Viçosa, Minas Gerais.

Almeida, M. E. C.; Vielliard, J. M. E. and Dias, M. M. (1999), Composição da avifauna em duas matas ciliares na bacia do rio Jacaré-Pepira, São Paulo, Brasil. Rev. Bras. Zool., 16 : (2), 1087-1098.

Andrade, R. D. and Marini, M. A. (2002), Bird species richness in natural forest patches in southeast Brazil. Lundiana, 3 : (2), 141-149.

Anjos, L. (2001), Bird communities in five Atlantic forest fragments in southern Brazil. Ornitologia Neotropical, 12, 11-27.

Argel-de-Oliveira, M. M. (1995), Aves e vegetação em um bairro residencial da cidade de São Paulo (São Paulo, Brasil). Revta bras. Zool., 12 : (1), 81-92.

(1996), Aves urbanas. In: Vielliard, J. M. E.; Silva, M. L. and Silva, W. R. (Eds.). Congresso Brasileiro de Ornitologia. Anais...Campinas : UNICAMP. pp. 151-162.

Beissinger, S. R. and Osborne, D. R. (1982), Effects of urbanization on avian community organization. Condor, 84, 75-83.

Bierregaard Jr., R. O. (1998), Conservation status of birds of prey in the South American tropics. J. Raptor Res., 32, 19-27.

Diniz-Filho, J. A. F. and Bini, L. M. (1996), Assessing the relationship between multivariate community structure and environmental variables, Mar. Ecol. Prog. Ser., 143, 303-306.

Foster, M. (1996), The potential of fruiting trees for habitat enhacement. In: Vielliard, J. M. E.; Silva, M. L. and Silva, W. R. (Eds.). Congresso Brasileiro de Ornitologia. Anais...Campinas : UNICAMP. pp. 141-142.

Fowler, J.; Cohen, L. and Jarvis, P. (1998), Practical Statistics for Field Biology. West Sussex : John Wiley and Sons. 
Gentry, A. H. (1986), Endemism in tropical versus temperate plant communities, In: Soulé, M. E. (Ed.). Conservation Biology - The science of scarcity and diversity. Massachussets : Sinauer Associates. pp. 153-181.

Gimenes, M. R. and Anjos, L. (2000), Distribuição espacial de aves em um fragmento florestal do campus da Universidade Estadual de Londrina, Norte do Paraná, Brasil. Rev. Bras. Zool., 17, 263-271.

Hostetler, M. and Knowles-Yanez, K. (2003), Land use, scale, and bird distributions in the Phoenix metropolitan area. Landscape Urban Plan, 62, 55-68.

Jokkimäki, J. and Suhonen, J. (1998), Distribution and habitat selection of wintering birds in urban environments. Landscape Urban Plan, 39, 253-263.

Kahn, J. R. and McDonald, J. A. (1997), The role of economic factors in tropical deforestation. In: Laurence, W. F. and Bierregaard Jr., R. O. (Eds.). Tropical forest remnants - ecology, management, and conservation of fragmented communities. Chicago; London : The University of Chicago Press. pp. 13 - 28 .

Karr, J. R. (1976), Seasonality, resource availability, and community diversity in tropical bird communities. Am. Nat., 110, 973-994.

Karr, J. R.; Robinson, S. K., Blake, J. G. and Bierregaard Jr., R. O. (1990), Birds of Four Neotropical Forests. In: Gentry, A. H. (Ed.). Four Neotropical Rainforests. New Haven; London : Yale University Press. pp. 237-269.

Krügel, M. M. and Anjos, L. (2000), Bird communities in forest remnants in the city of Maringá, Paraná State, Southern Brazil. Ornitol. Neotrop., 11, 315-330.

Magurran, A. E. (1988), Ecological Diversity and its measurement. London : Chapman and Hall.

Melles, S.; Glenn, S and Martin, K. (2003), Urban bird diversity and landscape complexity: Speciesenvironment associations along a multiscale habitat gradient. Conservation Ecology, 7 : (1), 5. [online]. Disp. in: http:www.consecol.org/vol7/ iss 1/art5.

Motta-Júnior, J. C. (1990), Estrutura trófica e composição das avifaunas de três habitats terrestres na região central do estado de São Paulo. Ararajuba, 1, 65-71.

Ricklefs, R. E. (1993), A economia da natureza. Rio de Janeiro : Guanabara Koogan.

Rohlf, F. J. (1996), NTSYS: numerical taxonomy and multivariate analysis system. New York : Applied Biostatistics, Inc. Exeter Software.
Santos, M. P. D. (2001), Composição da avifauna nas áreas de Proteção Ambiental Serra do Tabatinga e Chapada das Mangabeiras, Brasil. Bol. Mus. Para. Emílio Goeldi, ser. Zool., 17, 43-67.

Savard, L. J. P.; Clergeau, P. and Mennechez, G. (2000), Biodiversity concepts and urban ecosystems. Landscape Urban Plan, 48, 131-142.

Sick, H. (1997), Ornitologia brasileira. Rio de Janeiro : Nova Fronteira.

Silva, J. M. C. (1995), Birds of the Cerrado Region, South America. Steenstrupia, 21, 69-92.

Willis, E. O. (1979), The composition of avian communities in remanescent woodlots in southern Brazil. Pap. Avulsos Zool., 33 : (1), 1-25.

Wunderle Jr., J. M. (1994), Census Methods for Caribbean Landbirds. New Orleans : United States Department of Agriculture. Southern Forest Experiment Station. 